\title{
EVALUATION OF THE INTERNAL MANAGEMENT CONTROL SYSTEM - MAJOR OBJECTIVE IN THE PREPARATION AND ACHIEVEMENT OF THE PUBLIC INTERNAL AUDIT
}

\author{
Ioan Gabriel POPA, Valentin PÎRVUȚ \\ "Nicolae Bălcescu" Land Forces Academy, Sibiu, Romania \\ popaigabi@yahoo.com
}

\begin{abstract}
In public entities, the management is required to ensure the achievement of all the entity's objectives in an economic, efficient and effective manner, in compliance with the rules specific to the field, policy and management decisions, as well as the protection of goods and information, prevention and detection of fraud and error, quality of accounting documents and providing timely real and credible information. These objectives can only be achieved if a system of internal managerial control that includes all existing control forms, organizational structures, methods and procedures to ensure the management of funds available to public entities in an economic, efficient and effective way is implemented and developed at the level of the public entity. For at least once during a financial year, the internal management control system must be evaluated by comparing the obtained results with the proposed objectives, in order to identify the factors causing deviations from the baseline and to identify objective corrective or preventive measures to eliminate negative effects or deviations. In this context, it is considered that only public internal audit can carry out the assessment of the internal management control, as the audit, as an independent functional activity, can provide reasonable assurance through a systematic and methodical approach, aimed at improving the activities of the public entity, assisting it in fulfilling its aims.
\end{abstract}

Keywords: control, internal management control, public internal audit, evaluation, management, audit missions.

\section{Introduction}

After the issue of the Secretary General of the Government Order No. 400/2015 - for the approval of internal management control of public entities, an order regrouping the 25 internal management control standards in 16 standards, approved by order of the Ministry of Public Finance no. 946/2005, we need to study, implement and develop the latter in accordance with the size, complexity and environment specific to the economic entity.

The management of the public institution is required to develop and implement their own system of internal management control, starting from internal management control standards approved by law and also taking into account the good practices stipulated in the field. This model of internal management control measures should encompass all messures taken by the management and implemented by all staff in terms of organizational structure, procedures, tools and techniques applied in order to achieve the objectives of the public institution.

Certainly, the major concern of the management of the public institution, in terms of implementing a viable system of internal management control, is to ensure a continuous evaluation and assessment of its functionality and components, in order to timely identify weaknesses or 
deficiencies of the internal control and to take corrective actions ar actions meant to eliminate them in due time.

\section{Internal Management Control}

Nationally and internationally, there are many approaches to the concept of internal management control, which we will present below, in order to identify the essence, a thorough understanding of the concept and its demarcation from other forms of control or inspection.

At the level of EU countries, there are two main descriptive approaches of the internal control, namely [1]:

$>$ the first, according to which internal management control refers to the whole control system of the public administration and the sum of all institutions involved in exercising control of public funds, so the approach is more of an "internal control" (see Spain and Luxembourg). This control is completed with an external audit executed by the supreme audit institution and the parliament, and

the second, according to which internal management control in other E.U. countries is understood as the comprehensive and harmonized conceptual approach of the government to ensure the establishment, maintenance and monitoring by managers of all public entities of the integrated management processes. In these countries, the internal control aims to manage risks and to provide reasonable assurance regarding the achievement of the general objectives pursued in the mission of the entity.

As shown in official documents (see Compendium of Internal Public Control Systems in the Member States of the European Union 2012) in countries such as Greece and Slovakia, the internal management control system is defined by specific laws, while in other countries such as Finland, Hungary or Estonia, internal management control is included in the financial regulations (law of public finances, legislation approved by the government or guides) and in others, such as Denmark, the Netherlands or the United Kingdom, internal control is not mentioned explicitly, but a clear framework for internal control of institutions is created by the existing rules and regulations, the latter arguing the fact that they have implemented integrated components set by the model of the Committee of Sponsoring Organizations of the Treadway Commission (COSO) as well as by the standard guide for internal control in the public sector of the International Organization of Supreme Audit Institutions (INTOSAI).

From the above mentioned issue, it is very clear that the community in the field of internal control presents a deeply collaged character of differentiated application at the level of the E.U.

The legitimate questions that we will answer are: What is internal control? and Can it not be applied homogeneously?

According to COSO, internal management control is defined, in a broader sense, as "a process implemented by the Board, management and other staff members of an entity, that aims to provide reasonable assurance regarding the achievement of the following objectives: effectiveness and efficiency of operation, reliability of financial information, compliance with laws and regulations" [2].

According to the White Charter of the management reform within the European Commission services, "internal control covers all the policies and procedures designed and implemented by the management of the organization in order to ensure: achievement of the goals of the organization in an economic, efficient and effective manner, compliance with external rules and with policies and management rules, protection of assets and information, prevention and detection of fraud and errors and the quality of accounting documents and timely production of reliable information regarding the financial and management segment". 
According to the law in Romania, internal control "represents all forms of control exercised at the level of the public entity, including internal audit, established by management in accordance with its objectives and legal regulations in order to provide fund administration economically, efficiently and effectively; it also includes organizational structures, methods and procedures" [3] and "all policies and procedures developed and implemented by the public entity management in order to ensure: achievement of entity's goals in an economic, efficient and effective manner; compliance with field-specific rules, policies and management decisions; protection of goods and information, prevention and detection of fraud and error; quality of accounting documents and timely production of reliable information for the management" [4].

Under the tow definitions stipulated by the Romanian legislation, internal control represents all policies and procedures developed and implemented by management and by officials from all levels of the public entity, for the purpose of holding control on the overall operation of the public entity, of each activity/action so that the targets are achieved, in order to provide economical, efficient and effective fund administration and includes all forms of control exercised at the level of the public entity, including internal audit.

The analysis of the concepts commonly used in management practice emphasizes the idea that these concepts reflect four fundamental principles:

$>$ internal control is a process, a means to achieve a goal; internal control is carried out by people, which means that, in addition to textbooks, policies, instructions, documents, etc., the quality of the people at every level of the public entity has to be taken into account;

$>$ internal control provides reasonable assurance regarding the management of the entity related to the fact that the public entity's objectives will be met;

internal control helps ensure the achievement of the objectives of the public entity.

The process of design and implementation of the internal control system within each public entity is based on internal/management control standards approved by the Secretary General of the Government Order No. 400/2015, approving the Internal/Management Control Code for Public Entities. Internal Management Control Standards define the minimum management rules that all public entities must follow. The purpose of these standards is to create a uniform and consistent model of internal management control to allow comparisons between entities of the same kind or of the same entity at different times, and to make it possible to highlight the results of the entity and its evolution. Standards are a relative reference system used to assess internal/management control systems, identifying the areas and directions of change.

According to the Secretary General of Government Order 400/2015, these standards are grouped in five key elements, as shown in the diagram below:

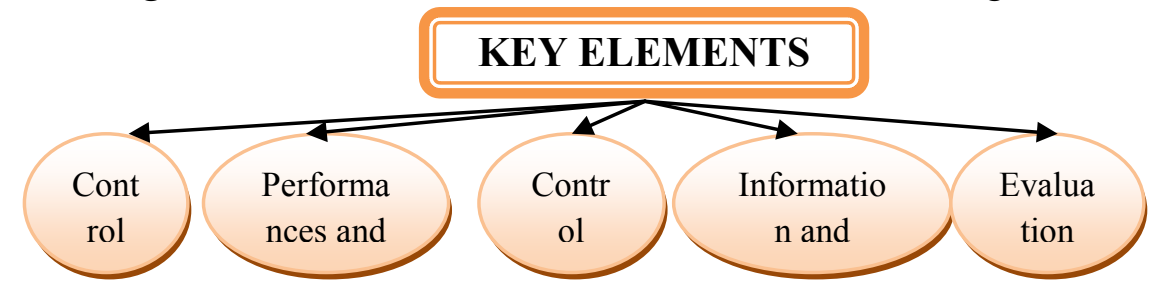

Figure 1: Key elements of the control system

Figure 1 shows that the components of the control system are closely interdependent, and arise from the manner in which the activities of the public entity are managed and integrated. 
Next we will focus only on the last element, "evaluation and audit", whose issues pertain to the development of the evaluation capacity of the internal / management control in order to ensure the continuity in improving the process.

\section{Public Internal Audit}

Public internal audit is a form of control exercised in the public institutions, a form of control that is included in the internal control management (see O.G.119 / 1999 - on internal control and preventive financial control and the Order of the General Secretary of the Government 400/2015 - approving the code of the internal management control of public entities) which is required to periodically evaluate the internal management control system and support public entity to identify and assess risk and implement measures to improve the process for mitigating risk and achieving the objectives set by the public entity.

According to the legislation, public internal audit is a "functionally independent and objective activity of insurance and counselling, designed to add value and improve the activities of the public entity; it helps the public entity to achieve its objectives, through a systematic and methodical approach, evaluates and improves the efficiency and effectiveness of risk management, of control and of governance processes" [5].

From this perspective, it is assessed on the one hand that the internal audit public does not overlap nor interfere in the management of risks by the management of the public entity and therefore will not be involved in developing audited procedures, but performs insurance activities, which represent objective examinations of evidence, made in order to provide public entities independent assessment of the process, and, on the other hand, since the audit has no hierarchical authority over the management of public entity, it can perform only advisory activities, designed to add value and improve the processes of governance in public entities, without the internal auditor assuming managerial responsibilities.

The insurance missions are conducted in accordance with the types of internal audit regulated by law and can be classified according to the diagram below [6]:

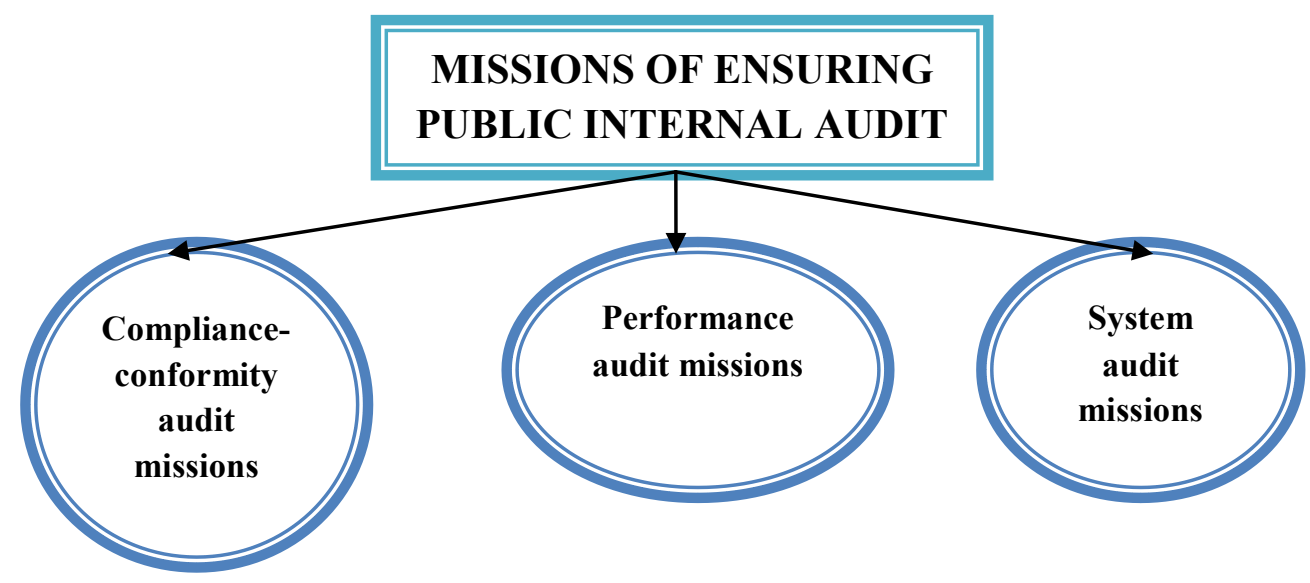

Figure 2: Missions of ensuring public internal audit

Each of these audit missions has its place and role in the process in order to give reasonable assurance to the public entity, as follows:

a) by planning and carrying out regular/compliance audits aimed to examine the effects of financial shares on public funds or public patrimony, in terms of overall compliance with the principles, procedural and methodological rules that are applied to them;

b) the performance audit mission is an independent and objective review of the activities / processes / programs / projects 
of an entity, designed to bring added value to them by assessing and comparing the results obtained with the proposed or expected objectives, in terms of economy, efficiency and effectiveness;

c) the system audit mission is an indepth assessment of the management internal control systems, aimed at determining whether they operate economically, efficiently and effectively, identifying weaknesses and making recommendations for their correction.

As seen from the characteristics of each mission of ensuring the internal audit listed above, only the system audit helps the organization maintain a system of internal / managerial control properly assessing and ensuring the efficiency and effectiveness of its improvement.

This aspect is also enforced by the design and implementation of the internal control system within each public entity, a process that is based on standards of internal / management control approved by Order no. 400/2015, i.e. standard 15, entitled "Assessment of the internal / management control" and standard 16, entitled "Internal Audit".

\section{Evaluation of the internal management control by public internal audit}

Evaluation of internal management control by the audit has mainly aims at evaluating its efficiency and effectiveness based on measuring or quantifying the risks associated with the auditable activities / actions and covers the following operations:

a) reliability and integrity of financial and operational information;

b) effectiveness and efficiency of processes / activities / operations;

c) heritage protection;

d) compliance with laws, regulations and procedures.

In order to assess internal control management, the audit must detect and analyze all forms of control implemented by the public entity as to identify associated risks and their management. Risks can identify after analyzing the existing documents and the information in the Permanent File or after carrying out analyzes or work procedures using the Internal Control Questionnaire. The purpose of this analysis is the discovery of any areas or sectors that are defective or malfunctioning. In this case, the audit is required to determine the extent to which the objectives and results are compliant with the set objectives and if the activities of the public entity are carried out in accordance with the existing procedures or under the conditions of performance.

Equally, the assessment of the internal management control system by audit involves evaluating and improving the governance process (set of principles underlying the governance framework through which the entity is managed and controlled) in order to promote ethical conduct and values in the public entity, ensuring effective management of performance and accountability and coordination of activities and communication of information on risk and control within the public entity.

It is assumed that the assessment of internal management control by audit involves the following steps and activities [7]:

a) determining the modalities of operation of each identified activity / action. This step detects expected internal controls, meaning all kinds of internal controls that should be implemented by the public entity or any activity, means or action that should be established and implemented by the management in order to have proper control over the functioning of the audited entity's structure as a whole, given the provisions of the regulatory framework.

b) establishing internal controls expected for each identified activity / action and risk. This step sets a benchmark or a minimum acceptable standard of the internal controls that should be implemented in the public entity that 
will allow auditors a basis for comparison when assessing. In this step, the identification of the expected controls is initiated based on the information summarized in the document "Preliminary study", the controls that are based on evidence collected during the course of the process entitled "Collecting and processing information".

c) identifying existing internal controls, based on Internal Control Questionnaire and collected documents. At this stage, internal controls are established for managing the risks at the level of the public entity. The consistency of the internal control when assessing the degree of confidence in internal control is also established based on these documents.

d) establishing internal control compliance. This step identifies and analyzes internal controls implemented by the entity to manage these risks in order to discover any areas where there are signals that it does not work or is inappropriate. This step summarizes the outcome of the initial assessment of internal control for each auditable activity / action.

\section{Conclusions}

The brief analysis of the internal management control system, on the one hand, and of the standards 15 and 16, on the other, standards that allow the use of existing internal specialized structures, called internal audit, aimed at performing the assessment of internal control management, permits us to draw some remarks:

* The success of the audit in testing all components of the internal control it considers likely of presenting uncontrolled risks vulnerable and in identifying activities that can generate major dysfunctions in some sectors of activity depends on the extent to which the audit manages to know in depth the internal management control system and on achieve a correct assessment of the hazards associated with its operation. In this case, the audit may establish appropriate measures to eliminate the dysfunctionalities found and may recommend introducing control devices so as to prevent, detect and correct errors and irregularities.

* The assessment of the internal control system by auditors allows them to issue an opinion regarding the functioning of the system in accordance with rules and procedures established by the management and to identify areas where they are not functional.

\section{References}

[1] Comisia Europeană, Compendiu al Sistemelor de Control Public Intern din Statele Membre ale Uniunii Europene 2012, Ed. Oficiul de Publicaţii al Uniunii Europene, Luxemburg, 2011, p.11;

[2] Emil MARE şi Marius Tomoială, Controlul intern/managerial, Ed. Ştef, Iaşi, 2012, p.29;

[3] Guvernul României, art.2, lit. c) din O.G.119/1999-privind controlul intern/managerial şi controlul financiar preventive, Ed. Monitorul Oficial al României nr. 430 din 31 august 1999, cu modificările şi completările ulterioar, Bucureşti,1999;

[4] Parlamentul României, art.2, lit. g) din Legea 672/2002-Legea privind auditul public intern, Ed. Monitorul Oficial al României nr. 24 decembrie 2002, cu modificările şi completările ulterioare Bucureşti, 2002;

[5] Parlamentul României, art.2, lit. a) din Legea 672/2002-Legea privind auditul public intern, Ed. Monitorul Oficial al României nr. 24 decembrie 2002, cu modificările şi completările ulterioare București, 2002;

[6] Guvernul României, Hotărâre Guvernului nr. 1086 din 11 decembrie 2013 - pentru aprobarea Normelor generale privind exercitarea activităţii de audit public intern. Capitolul III, Ed. Monitorul Oficial al României nr. 17 ianuarie 2014. Bucureşti, 2014; 
[7] Unitatea Centrală de Armonizare pentru Auditul Public Intern, Indrumar-Evaluarea controlului intern în scopul realizării misiunilor de audit public intern, disponibil la adresa http://discutii.mfinante.ro/static/10/Mfp/audit/Indrumar_EvaluareCI.pdf. 